\title{
MENINGKATKAN ERP-EFFICACY MAHASISWA PSIKOLOGI MELALUI ODOO HUMAN CAPITAL TRAINING
}

\author{
Dian Juliarti Bantam, Arief Fahmie, Emi Zulaifah \\ Fakultas Psikologi dan Sosial, Universitas Islam Indonesia \\ E-mail: dianjuliartibantam.psikologi@gmail.com
}

\begin{abstract}
This reserach examined the effect of Odoo Human Capital Training (OHCT) to improve ERP-Efficacy of psychology students. The reasearch is an intervention to improve efficacy about ERP softwares. This research used classroom action research (CAR) method of quasi experimental type with nonequivalent control group with pretest and posttest design. The participants were 35 students, with 18 students assigned to experimental group and 17 students to control group. The experimental group was trained for 4-5 hours each day within two days. The ERP-Efficacy was mesured by the ERP-Efficacy Questionnaire (ERPEQ) using 3 aspect from Compeau dan Higgins (1995). The aspect are ERP magnitude, ERP strength, and ERP generalizability. The data were analyzed by using anava mixed design. The result showed there was a significant difference of ERP-Efficacy between experimental and control group for pretest, posttest and follow up observations, with a value of $F=37.25$ and $p=0.000(p<0.05)$. These hypothesis of this research that the effect of OHCT can improve the ERP-Efficacy among psychology students were accepted.
\end{abstract}

Key words: Odoo Human Capital Training, Enterprise Resource Planning, Efficacy.

\begin{abstract}
Abstrak
Penelitian ini bertujuan untuk menguji efek dari pelatihan Odoo Human Capital untuk meningkatkan ERP-Efficacy pada mahasiswa psikologi. Penelitian ini merupakan intervensi sebagai upaya untuk meningkatkan keyakinan tentang penggunaan berbagai perangkat lunak ERP. Penelitian ini menggunakan metode penelitian tindakan kelas (PTK) jenis kuasi eksperimen dengan rancangan nonequivalent control group with pretest and posttest design. 35 mahasiswa ikut berpartisipasi dalam penelitian ini, dengan pembagian 18 sebagai kelompok eksperimen dan 17 sebagai kelompok kontrol. Kelompok eksperimen dilatih selama 4 sampai 5 jam per hari dengan masa pelatihan 2 hari. ERP-Efficacy diukur dengan menggunakan ERP-Efficacy Questionnaire (ERP-EQ) dengan menggunakan 3 aspek dari Compeau dan Higgins (1995). Aspek-aspek tersebut yaitu ERP magnitude, ERP strength, dan ERP generalizability. Analisis data menggunakan anava desain campuran. Hasil penelitian menunjukkan bahwa adanya perbedaan yang signifikan pada kedua kelompok saat pengamatan pretes, postes dan tindak lanjut, dengan nilai $F=37.25$ dan $p=$ $0.000(\mathrm{p}<0.05)$. Artinya hipotesis penelitian ini yang menyatakan bahwa pelatihan Odoo HC dapat meningkatkan ERP-Efficacy mahasiswa psikologi diterima.
\end{abstract}

Kata kunci: Pelatihan Odoo Human Capital, Enterprise Resource Planning, Efficacy. 


\section{PENDAHULUAN}

Perusahaan saat ini, membutuhkan lulusan yang tidak hanya memiliki IPK cumlaude, tetapi juga memiliki keterampilan yang ssesuai bidang kerja dan keterampilan khusus yang mendukung seperti teknologi, serta sikap yang menjunjung integritas. Sebagaimana yang dikemukakan Cummings dan Worley (2009) bahwa efektvitas perusahaan tergantung dari beberapa aspek diantaranya SDM, sistem manajemen perusahaan, teknologi, pengembangan SDM, dan penilaian efektivitas keseluruhan aspek perusahaan. Salah satu teknologi informasi yang popular dan pengembangannya masih terus dioptimalkan di berbagai perusahaan yaitu Sistem Informasi Sumber Daya Manajemen, yang lebih dikenal dengan enterprise resource planning (ERP). Menurut Monk dan Wagner (2013), ERP system merupakan sistem informasi yang mengintegrasikan dan mengkoordinasikan seluruh data dan proses dari suatu perusahaan menjadi sistem bisnis terpadu. Aktivitas yang dimaksud yaitu proses produksi, akuntasi, projek, penjualan sampai dengan proses sumber daya manusia perusahaan, misalnya rekrutmen, promosi, appraisal, pelatihan dan pengembangan.

Elmeziane dan Elmeziane (2012), mengemukakan bahwa ERP memainkan peran penting dan mulai menjadi tulang punggung bagi performansi organisasi. Kebutuhan perusahaan tersebut, membuat dunia pendidikan mencari cara untuk meningkatkan kualitas SDM. Sebagaimana usaha yang dilakukan oleh salah satu Universitas Swasta di Yogyakarta (Universitas X), khususnya Program Studi Psikologi. Hal ini diwujudkan dalam mata kuliah Human Resource Information System (HRIS) berupa pengimplementasian pembelajaran psikologi industri dan organisasi yang lebih dikenal dengan human capital management (HCM) berbasis IT.

Proses HCM yang ada di Prodi Psikologi Universitas X diajarkan dalam bentuk pelatihan. Pelatihan yang ada digunakan sebagai salah satu aplikasi problem-based learning pembelajaran ERP-HCM (ERP system modul atau aplikasi human capital). Pembelajaran ERP-HCM berbasis problem-based learning yang diimplementasikan bertujuan pengaplikasian teori Psikologi Industri dan Organisasi khususnya proses HCM, sehingga mudah dipahami mahasiswa dan menghasilkan alumni yang memiliki pengetahuan dan keterampilan di bidang industri. Dengan adanya fasilitas yang disediakan oleh sebuah Universitas untuk menjawab kebutuhan perusahaan, maka idealnya para lulusan atau mahasiswa, sudah siap dan yakin untuk bekerja. Selain itu, idealnya juga mahasiswa telah memiliki keyakinan untuk dapat beradaptasi dengan lingkungan pekerjaan, baik dari segi hubungan antar karyawan sampai adaptasi dengan alat yang digunakan perusahaan. Artinya keyakinan mereka dalam penggunaan alat atau software yang membantu kinerja perusahaan sangat dibutuhkan.

Penelitian Compeau dan Higgins (1995), menemukan bahwa individu yang memiliki software efficacy rendah akan mengevaluasi dirinya tidak mampu untuk 
menggunakan software atau teknologi, sehingga membuatnya kurang mampu berinteraksi dengan IT. Pendapat ini sejalan dengan pendapat Lunenburg (2011), bahwa efficacy seseorang akan berbeda-beda. Ada individu yang meyakini bahwa dirinya mampu mengerjakan sebuah tugas, tetapi ada individu lain yang merasa tidak yakin mengerjakan tugas yang sama. Keyakinan positif individu dalam menggunakan IT perlu dipupuk sejak dini, dikarenakan kurangnya keyakinan akan kemampuan penggunaan software akan menghambat inidividu untuk mencapai kinerja optimal di perusahaan (Lunenburg, 2011).

Banyak penelitian yang mengkaji terkait keyakinan individu dalam menggunakan sistem informasi yang akan mempengaruhi perilaku. Salah satunya Sam, Othman, dan Nordin (2005) menyatakan bahwa computer self-efficacy (CSE) atau technology selfefficacy merupakan tipe yang spesifik dari self-efficacy. Artinya CSE sebagai bagian dari self-efficacy yang dipengaruhi oleh keyakinan maupun persepsi individu. ERPEfficacy juga merupakan bagian yang lebih spesifik dalam konteks teknologi yaitu bagian software. Menurut Bandura (Compeau dan Higgins, 1995), Chou, Hsiao, Shen dan Chen (2010), serta Lunenburg (2011), ada beberapa faktor yang mempengaruhi efficacy seseorang diantaranya pengalaman masa lalu (past performance), pengalaman orang lain (vicarious experience), pendekatan persuasi (verbal persuation), dan efek psikologis (emotional cues). Pengalaman masa lalu menjadi faktor terkuat, dikarenakan ketika individu berhasil atau mencapai kesuksesan di masa lalu, maka individu tersebut akan mengembangkan keyakinan keberhasilan di masa mendatang. Menurut Compeau dan Higgins (1995) serta Farah (2011), pelatihan atau penambahan keterampilan bagi individu menjadi sangat penting. Dengan begitu, individu telah memiliki keterampilan yang dapat digunakan untuk mengatasi hambatan dalam tugas, sehingga membuatnya lebih matang dan siap.

Supratiknya (2008) menyatakan bahwa pelatihan ERP dilakukan sebagai upaya peningkatan kekurangan keterampilan dan pengetahuan dari individu. Gazda mengatakan bahwa bentuk intervensi terhadap kekurangan keterampilan adalah mengajarkan jenis-jenis keterampilan yang dibutuhkan (Supratiknya, 2008), sehingga pelatihan ini difokuskan untuk peningkatan pengetahuan, keterampilan dan sikap mahasiswa terhadap konsep ERP Human Capital, dengan menggunakan salah satu satu software ERP yaitu Odoo dengan aplikasi human capital (Sumber Daya Manusia). Raza, Zia, Naqvi dan Shaikh (2011) juga mengemukakan bahwa pelatihan pengembangan SDM yang memadai dapat menyebabkan pengembangan self-efficacy. Dinamika yang tejadi yaitu peningkatan human capital (pengetahuan, keterampilan dan pengalaman) dapat menyebabkan pengembangan social capital yang disebut dengan network atau hubungan sosial, hasil akhir yang dapat diperoleh yaitu peningkatan psikologis yang positif yang terdiri dari peningkatan kepercayaan diri, pengharapan, optimisme dan kesiapan secara psikologis dalam melakukan sesuatu. 
Pelatihan ini dibutuhkan untuk meningkatkan ERP-Efficacy mahasiswa. Compeau dan Higgins (1995) serta Hommes dan Molen (2012), menyatakan ahwa ERP-Efficacy individu dapat ditingkatkan melalui intervensi yang tepat. Oleh karena itu, pelatihan Odoo HC ini, dirancang untuk meningkatkan pengetahuan, keterampilan dan sikap, yang akan meningkatkan ERP-Efficacy mahasiswa yang mengalami kekurangan. Pelatihan Odoo Human Capital (Odoo HC) merupakan pelatihan berbasis problembased learning. Artinya pelatihan ini, dilakukan untuk mengatasi kekurangan atau keterbatasan mahasiswa psikologi terkait ERP human capital. Prinsip dari pelatihan Odoo $\mathrm{HC}$ yang penting adalah proses belajar itu dapat terjadi melalui pengalaman yang dimulai dan dialami oleh mahasiswa sendiri (experiential learning). Pelatihan ini melibatkan berbagai aktivitas seperti mengalami (experiencing), membagikan pengalaman (publishing), memproses pengalaman, merumuskan kesimpulan dan menerapkan atau merencanakan cara penerapan hasil belajar.

Odoo merupakan salah satu software open source dari Sistem Enterprise Resource Planning (ERP). Dalam software Odoo tersebut terdapat beberapa aplikasi (modul) atau fiture bisnis, salah satunya human capital application atau human capital module. Human Capital Function yang terdapat dalam Odoo system dan dapat digunakan secara gratis yaitu struktur organisasi, rekrutmen dan seleksi, employee directory (data pribadi karyawan), cuti, penilaian karyawan, jadwal kerja karyawan, dan payroll system. Dalam pelatihan ini hanya beberapa fungsi yang digunakan yaitu struktur organisasi, struktur karyawan/employee directory, rekrutmen dan cuti. Ada beberapa keunggulan yang dapat dirasakan dari mengikuti pelatihan ini. Pertama, Pelatihan Odoo HC menggunakan metode penambahan pengetahuan (kognitif) mahasiswa yaitu sejumlah materi, penjelasan dan informasi, terkait proses kerja yang berhubungan dengan human capital di perusahaan, penjelasan Odoo software, ERP-system, dan pemberian informasi terkait perusahaan-perusahaan pengguna ERP.

Kedua, Pelatihan Odoo HC menggunakan metode pembelajaran langsung atau praktek, sehingga mahasiswa dapat mengimplementasikan pembelajaran human capital melalui IT. Sebagaimana yang dikemukakan oleh Hommes dan Molen (2012) bahwa pelatihan dibutuhkan untuk meningkatkan efficacy melalui praktek langsung untuk peningkatan suatu keterampilan. Beberapa penelitian sebelumnya menunjukkan bahwa pelatihan dengan praktek langsung menggunakan komputer atau teknologi akan sangat membantu meningkatkan efficacy individu dalam penggunaan teknologi (Aremu \& Fasan, 2011; Farah, 2011; Sabzian dan Gilakjani, 2013; Singh, 2015).

Manfaat penelitian ini secara teoritis adalah dapat memberikan sumbangan pada penelitian sebelumnya maupun penelitian mendatang, terkait ERP-Efficacy mahasiswa maupun terkait pengimplementasian software berbasis human capital management. Sedangkan manfaat praktis yang akan dirasakan dari adanya pelatihan ini adalah dapat memberikan gambaran sejauh mana pengaruh pelatihan Odoo human capital terhadap 
ERP-Efficacy mahasiswa psikologi. Apabila ada pengaruh antar variabel tersebut, maka dapat digunakan serangkain prosedur dalam pelatihan ini untuk pembelajaran mahasiswa pada mata kuliah HRIS di Program Studi Psikologi. Rangkaian prosedur yang dimaksudkan yaitu dimulai dari pengisian kuesioner ERP-Efficacy berbasis website sampai mengikuti pelatihan/pembelajaran Odoo Human Capital.

Berdasarkan pemaparan latar belakang dan landasan teori tersebut, maka hipotesis dalam penelitian ini adalah Odoo HC Training dapat meningkatkan ERP-Efficacy pada mahasiswa Psikologi.

\section{METODE}

Variabel dependen dalam penelitian ini adalah ERP-Efficacy (ERPE), yang merupakan penilaian keyakinan individu terhadap kemampuan dirinya dalam mengorganisasi dan mengoperasikan serangkaian aplikasi atau modul dari software sistem ERP yang dapat mengintegrasikan berbagai proses bisnis perusahaan sehingga menjadi terpadu. Sedangkan variabel bebas dalam penelitian ini adalah pelatihan Odoo HC (OHCT), yang merupakan pelatihan berbasis problem-based learning, yang diberikan untuk mengatasi keterbatasan pengetahuan, keterampilan dan sikap mahasiswa, dalam penggunaan software ERP fungsi human capital.

\section{Partisipan}

Subjek penelitian diambil dengan cara nonrandom yaitu melalui purposive sampling. Pusposive sampling adalah teknik memperoleh sampel penelitian berdasarkan kriteria yang sudah ditentukan sebelumnya sehingga relevan dengan pelatihan (Cozby, 2009). Penentuan sampel menggunakan judgement sampling, yaitu pengambilan sampel berdasarkan penilaian dari hasil kategorisasi ERP-EQ dan hanya subjek yang memiliki ERP-Efficacy sedang sampai sangat rendah yang diikutkan pada pelatihan ini.

\section{Design}

Rancangan penelitian ini menggunakan Penelitian Tindakan Kelas, yang di desain sesuai dengan situasi kelas untuk meningkatkan kualitas pembelajaran. Menurut Arikunto, Suharjono, dan Supardi (Muliawan, 2010) PTK merupakan salah satu bentuk penelitian yang dilakukan di kelas. PTK yang digunakan pada penelitian ini adalah penelitian eksperimen, maka model rancangan eksperimen yang digunakan merupakan model yang dikemukakan oleh Cambell dan Stanley (Shaughnessy, Zechmeister \& Zechmeister, 2012) yaitu desain kelompok kontrol nonekuivalen (Nonequivalent Control Group Design With Pretest and Posttest). Berikut desain eksperimen yang digunakan: 
Tabel 1

Desain Ekserimen Nonequivalent Control Group Design

With Pretest and Posttest

\begin{tabular}{cccc}
\hline Grup & Pretes & $\mathbf{X}$ & Postes \\
\hline Eksperimen & $\mathrm{O}_{1}$ & ODDO HC & $\mathrm{O}_{2}$ \\
\hline Kontrol & $\mathrm{O}_{3}$ & - & $\mathrm{O}_{4}$ \\
\hline
\end{tabular}

\section{Instrumen dan Metode Pengambilan Data}

Ada beberapa metode pengumpulan data yang digunakan dalam penelitian ini yaitu skala, wawancara dan observasi. Skala atau ERP-Efficacy Questionnaire (ERP-EQ) dibuat oleh peneliti berdasarkan karakteristik subjek penelitian dengan mengacu pada aspek Computer Self-Efficacy dari Compeau dan Higgins (1995), dan teori ERP dari Monk dan Wagner (2013), yaitu terdiri tiga aspek, meliputi aspek ERP magnitude, ERP strength, dan ERP generalizability. Pengukuran ERP-EQ ini mengikuti rating scale dengan enam alternatif jawaban kuantitatif yaitu 1 (sangat tidak mampu) sampai dengan 6 (sangat mampu) yang menyatakan tingkat ERP-Efficacy.

Wawancara dilakukan kepada kelompok eksperimen sesudah diberi perlakuan. Wawancara dilakukan untuk mengetahui efek dari perlakuan yang diberikan serta mengetahui sejauh mana pengaplikasian modul dan pelatihan Odoo HC yang diberikan. Observasi dilakukan selama pelatihan berlangsung yaitu dengan bantuan observer, berlandaskan indikator perilaku yang sebelumnya telah dibuat oleh peneliti (Dapat dilihat pada lampiran). Pada penelitian ini terdapat tiga observer yang akan membantu jalannya pelatihan. Observer merupakan mahasiswa magister psikologi profesi yang telah selesai melakukan Praktek Kerja Profesi Psikologi (PKPP).

Tugas rumah diberikan dengan catatan subjek dapat melihat kembali modul yang diberikan saat pelatihan. Hal ini dimaksudkan agar melatih kemampuan kognitif dan keterampilan dalam menggunakan software Odoo modul Human Capital. Tugas rumah akan diberikan pada hari pertama pelatihan dan didiskusikan pada hari kedua pelatihan. Tugas rumah berupa pengerjaan salah satu proses HR (rekrutmen) yang ada di modul pembelajaran tersebut. Tugas rumah diberikan untuk melihat apakah subjek mengaplikasikan modul dan materi yang diberikan dan mengetahui efektivitas dari program ini serta subjek dapat belajar secara mandiri menggunakan software Odoo Human Capital.

\section{Prosedur}

Pelatihan Odoo HC dilakukan untuk meningkatkan keterampilan penggunaan software ERP, sehingga lebih memungkinkan bagi subjek yang memiliki ERP-Efficacy sangat rendah sampai sedang dan bersedia mengikuti pelatihan, dibandingkan subjek yang memiliki ERP-Efficacy tinggi. Selain itu, dapat dijelaskan bahwa baik kelompok 
kontrol maupun kelompok eksperimen akan diberikan pengukuran awal (pretes) yaitu 2 (dua) minggu sebelum pelatihan. Kemudian kelompok eksperimen akan diberi perlakuan berupa Pelatihan Odoo HC selama dua hari. Sedangkan kelompok kontrol akan dijadikan waitting list artinya akan diberi perlakuan setelah serangkaian penelitian berakhir. Setelah program selesai, peserta akan diberikan pengukuran lagi (postes) baik kelompok eksperimen maupun kelompok kontrol yaitu setelah 2 (dua) minggu pelatihan berakhir. Kurang lebih 2 (dua) minggu setelah postes akan diadakan tindak lanjut untuk mengetahui efek yang lebih lanjut terkait dampak Odoo HCT.

Alat ukur yang sama akan digunakan pada pretes, postes maupun tindak lanjut yaitu menggunakan ERP-Efficacy Questionnaire (ERP-EQ), yang telah melalui proses uji coba dan analisis aitem terlebih dahulu. Tujuan penggunaan alat ukur yang sama, agar hasilnya dapat dibandingkan. Pretes memberikan gambaran tentang kemampuan awal subjek sebelum diberikan pelatihan. Pretes, postes, tindak lanjut berguna untuk mengukur efek perubahan yang terjadi akibat pelatihan yang diberikan. Skor yang diperoleh merupakan peningkatan atau penurunan ERP-Efficacy subjek akibat efek dari pelatihan Odoo HC.

Proses analisis data yang digunakan dalam penelitian ini adalah analisis data kuantitatif berupa analisis skala ERP-EQ dan evaluasi reaksi serta analisis data kualitatif berupa evaluasi pengetahuan, wawancara dan observasi. Analisis data kuantitatif menggunakan anava mixed design (anava desain campuran) seperti yang disarankan oleh Widhiarso (2011), dengan bantuan program Statistical Product and Service Solution (SPSS) 16.0 realease for Windows. Uji hipotesis dilakukan untuk mengetahui efektivitas Odoo Human Capital Training dalam meningkatkan ERP-Efficacy pada mahasiswa psikologi antara kelompok eksperimen dan kelompok kontrol.

\section{HASIL}

Hipotesis dalam penelitian ini adalah Odoo Human Capital Training dapat meningkatkan ERP-Efficacy pada Mahasiswa Psikologi. Pengujian hipotesis menggunakan anava mixed design (Anava Desain Campuran). Analisis ini digunakan untuk mengetahui ada tidaknya perbedaan peningkatan ERP-Efficacy pada Mahasiswa Psikologi antara kelompok kontrol dan kelompok eksperimen.

Berdasarkan data statistik deskriptif tabel 2 diketahui bahwa rata-rata dan standar deviasi (SD) dari pretes, postes dan tindak lanjut pada kelompok eksperimen dan kelompok kontrol. Dari data tersebut dapat disampaikan bahwa ada kenaikan ERP Efficacy dari pretes yaitu sebesar 34.222 ke postes yaitu sebesar 58.222 dan naik juga pada saat tindak lanjut yaitu 64,222. Sebaliknya, pada kelompok kontrol ada kecenderungan penurunan ERP Efficacy dari pretes ke postes dan tindak lanjut. Artinya, setelah diberikan pelatihan Odoo HC terjadi peningkatan skor yang signifikan 
pada kelompok eksperimen, baik pada postes maupun tindak lanjut, sedangkan kelompok kontrol mengalami penurunan sekalipun tidak signifikan atau relatif sama.

Tabel 2

Data Deskriptif ERP-Efficacy

\begin{tabular}{lllcl}
\hline \multicolumn{1}{c}{ Perlakuan } & \multicolumn{1}{c}{ Kelompok } & Mean & Std. Deviation & N \\
\hline Pretes & Eksperimen & 34.2222 & 12.21164 & 18 \\
\cline { 2 - 5 } & Kontrol & 30.6471 & 13.26622 & 17 \\
\cline { 2 - 5 } & Total & 32.4857 & 12.67552 & 35 \\
\hline \multirow{2}{*}{ Postes } & Eksperimen & 58.2222 & 12.32193 & 18 \\
\cline { 2 - 5 } & Kontrol & 28.2941 & 12.55869 & 17 \\
\cline { 2 - 5 } & Total & 43.6857 & 19.50531 & 35 \\
\hline \multirow{2}{*}{ Tindak Lanjut } & Eksperimen & 64.2222 & 11.06428 & 18 \\
\cline { 2 - 5 } & Kontrol & 27.4706 & 10.36290 & 17 \\
\cline { 2 - 5 } & Total & 46.3714 & 21.42578 & 35 \\
\hline
\end{tabular}

Tabel 3

Test of Within-Subjects Effects ERP-Efficacy

\begin{tabular}{|c|c|c|c|c|c|c|}
\hline Variabel & \multicolumn{3}{|c|}{ Rata-Rata } & $\mathbf{F}$ & p & Keterangan \\
\hline \multirow{2}{*}{ ERP Efficacy } & Pretes & Postes & Tindak Lanjut & & & \\
\hline & 32.4857 & 43.6857 & 46.3714 & 37.250 & 0.000 & Signifikan \\
\hline
\end{tabular}

Berdasarkan table 3: Test of Within-Subjects Effects didapatkan hasil nilai $\mathrm{F}=$ 37.250 ( $\mathrm{p}<0.05$ ) artinya terdapat interaksi atau pengaruh antar perlakuan (pretes, postes dan tindak lanjut) dan antar kelompok (eksperimen dan kontrol). Interaksi menunjukkan adanya perubahan skor pretes menuju postes dan tindak lanjut pada kedua kelompok, mengalami perbedaan secara signifikan. Dengan kata lain, adanya perbedaan pengaruh setelah diberikan pelatihan Odoo HC pada kelompok eksperimen dan kelompok kontrol. Ketika diketahui adanya interkasi atau pengaruh perlakuan pada kedua kelompok. Maka peneliti melakukan analisis lanjutan terhadap data hasil pengukuran. Hal ini dilakukan untuk menganalisa sejauhmana konsistensi perubahan yang terjadi dan melihat perbedaan antara pretes, postes dan tindak lanjut diantara setiap kelompok penelitian. Analisis lanjutan ini menggunakan uji pairwise comparisons, hasil yang diperoleh pada tabel 4:

Berdasarkan hasil uji perbandingan pretes dan postes kelompok eksperimen perebedaan skor sebesar -24 dengan $p=0.000<0.05$. Rata-rata postes lebih tinggi daripada pretes, artinya mengalami peningkatan. Hasil tersebut menunjukkan bahwa ada pengaruh yang signifikan setelah diberikan pelatihan. Pengaruh tersebut yaitu adanya 
peningaktan skor ERP-Efficacy yang signifikan sebelum dan sesudah pelatihan Odoo HC pada kelompok eksperimen. Oleh karena itu, dapat dikatakan bahwa Pelatihan Odoo HC yang diberikan kepada kelompok eksperimen efektif dalam meningkatkan ERPEfficacy pada mahasiswa psikologi. Pada kelompok kontrol, saat pretes dan postes diperoleh skor perbedaan 2.353 dengan $p=0.513>0.05$. Hasil tersebut menunjukkan bahwa tidak ada pengaruh yang signifikan pada kelompok kontrol.

Tabel 4

Perbandingan Pretes-Postes ERP-Efficacy

\begin{tabular}{lllrcl}
\hline Kelompok & Pretes & Postes & Perbedaan & p & Keterangan \\
\hline Eksperimen & 34.2222 & 58.2222 & -24 & 0.000 & Signifikan \\
\hline Kontrol & 30.6471 & 28.2941 & 2.353 & 0.513 & Tidak Signifikan \\
\hline
\end{tabular}

Tabel 5

Perbandingan Postes dan Tindak Lanjut ERP Efficacy

\begin{tabular}{llclll}
\hline Kelompok & Postes & $\begin{array}{c}\text { Tindak } \\
\text { Lanjut }\end{array}$ & Perbedaan & $\mathbf{P}$ & Keterangan \\
\hline Eksperimen & 58.2222 & 64.2222 & -6 & 0.000 & Signifikan \\
\hline Kontrol & 28.2941 & 27.4706 & 0.824 & 0.569 & Tidak Signifikan \\
\hline
\end{tabular}

Perbedaan rata-rata postes dan tindak lanjut menunjukkan bahwa ada perubahan signifikan ( $\mathrm{p}<0,05)$ ERP-Efficacy pada kelompok eksperimen sebesar -6, sedangkan perubahan ERP-Efficacy pada kelompok kontrol tidak signifikan $(0.824, \mathrm{p}>0.05)$. Selain itu, jika dilihat pada nilai kelompok eksperimen saat postes dan tindak lanjut, diketahui bahwa kelompok eksperimen mengalami peningkatan skor ERP-Efficacy, sedangkan kelompok kontrol mengalami penurunan skor. Menunjukkan bahwa ada efek jangka panjang pada mahasiswa psikologi yang mengikuti pelatihan Odoo HC.

Selain data tersebut, peneliti juga melakukan analisis terkait sumbangan efektif dari pelatihan Odoo HC, terhadap peningkatan ERP-Efficacy kedua kelompok. Uji sumbangan efektif pelatihan menggunakan Multivariate Test, dengan melihat kolom Wilks' Lambda (Leech, Barret, \& Morgan, 2005) pada tabel 6.

Tabel 6

Hasil Mulivariate Test Kelompok Eksperimen dan Kontrol

\begin{tabular}{ccccc}
\hline Kelompok & Value & P & Partial Eta Squared & \% \\
\hline Eksperimen & 0.237 & 0.000 & 0.763 & $76.3 \%$ \\
\hline Kontrol & 0.963 & 0.551 & 0.037 & $3.7 \%$ \\
\hline
\end{tabular}

Dari tabel diatas diketahui nilai multivariate test pada kelompok eksperimen sebesar 0.237 dengan $\mathrm{p}=0.000$, dan tertulis nilai partial eta square sebesar 0.763 artinya ada 
pengaruh yang diberikan dari pelatihan Odoo HC dalam meningkatkan ERP-Efficacy mahasiswa sebesar 76.3\%. Sedangkan peningkatan kelompok kontrol hanya sebesar 3.7 $\%$ (partial eta square $=0.037, \mathrm{p}=0.551)$.

Berdasarkan serangkaian hasil uji anova mixed design yang telah dilakukan antara kelompok eksperimen dan kelompok kontrol saat pretes, postes, maupun pengukuran lanjutan, maka dapat disimpulkan bahwa hipotesis penelitian yang menyatakan Odoo HC Training dapat meningkatkan ERP-Efficacy pada mahasiswa Psikologi diterima. Pelatihan Odoo HC yang diberikan terbukti dapat meningkatkan ERP-Efficacy pada mahasiswa psikologi dengan sumbangan efektif sebesar $76.3 \%$.

\section{PEMBAHASAN}

Penelitian ini bertujuan untuk meningkatkan ERP-Efficacy mahasiswa psikologi dengan memberikan pelatihan Odoo Human Capital. Kelompok eksperimen menunjukkan ERP-Efficacy yang selalu naik secara signifikan dari pretes ke postes dan ke tindak lanjut. Hal ini menunjukkan bahwa Odoo Human Capital Training mampu meningkatkan ERP-Efficacy pada mahasiswa. Hasil ini sejalan dengan beberapa penelitian yang telah dilakukan, bahwa pelatihan atau intervensi yang melibatkan praktek langsung dari peserta, memiliki sumbangan yang sangat besar dalam meningkatkan keyakinan atau self-efficacy terhadap sebuah pembelajaran dan dapat menyiapkan peserta menjadi lebih matang (Compeau \& Higgins, 1995; Sabzian \& Gilakjani, 2013, Ikonomopoulos, Vela, Smith, \& Dell'Aquila, 2016). Praktek juga meningkatkan sef efficacy dalam konteks lain, seperti kemampuan psikomotor, (Wiyati, Widayanti \& Wahyuningsih, 2010), penggunaan komputer atau aplikasi (Berkant, 2016; Farah, 2011) dan juga self efficacy secara umum (Raza, dkk., 2011).

Hasil di atas menunjukkan bahwa pengalaman langsung menggunakan komputer dapat meningkatkan keyakinan di masa yang akan datang. Berkant (2016) menyatakan bahwa mahasiswa yang memiliki komputer atau orang yang sering menggunakan komputer memiliki level computer self-efficacy yang lebih tinggi dibandingkan dengan orang yang tidak memiliki komputer pribadi. Hal ini dikarenakan, orang yang memiliki komputer sering berinteraksi dengan PC tersebut dan tidak takut mencoba. Penelitian Farah (2011) juga menyatakan bahwa salah satu faktor yang dapat mempengaruhi technology self-efficacy para pengguna teknologi yaitu pengembangan profesional (pelatihan terkait teknologi yang dibutuhkan). Dengan adanya pelatihan tersebut dapat membantu pengguna menyelesaikan trouble shooting baik terkait hardware ataupun software, sehingga peserta memiliki kepercayaan diri dan kesiapan ketika dihadapkan dengan pekerjaan keseharian mereka. Selanjutnya Irfani (2015) menyatakan bahwa pelatihan penggunaan ERP sangat diperlukan dalam sebuah organisasi, terutama agar membuat pengguna merasa nyaman dan siap menggunakan software ERP yang akan 
diimplementasikan. Irfani (2015) juga mengungkapkan bahwa terdapat 3 aspek yang perlu dipertimbangkan tentang isi pelatihan yaitu logika dan konsep ERP, fitur dan sistem ERP, serta fungsional pelatihan. Logika dan konsep ERP akan memberitahukan pengguna atau peserta pelatihan tentang tujuan implementasi software ERP.

Melalui praktek langsung dapat mengubah kekhawatiran dan rasa kurang yakin terhadap penggunaan software di masa yang akan datang, sehingga pengguna akan merasa yakin dan siap ketika bekerja. Menurut Compeau dan Higgins (1995) perubahan pola pikir dan keyakinan ketidakmampuan penggunaan komputer, diharapkan dapat merubah sikap yang tidak yakin menjadi lebih yakin dan siap dalam menerapkan software atau tugas tertentu. Perubahan ini dapat diperoleh melalui pengalaman yang dialaminya sendiri maupun dari orang lain (Compeau \& Higgins, 1995; Wang \& Ertmer, 2015; Berkant, 2016).

Berdasarkan hasil wawancara, para peserta menyatakan bahwa telah siap untuk menggunakan software ERP. Para peserta menyatakan bahwa mereka siap menggunakan software sejenis atau yang lebih rumit. Hal ini sesuai dengan pendapat Teo dan Koh (2010) yang menyatakan bahwa individu dengan computer self-efficacy tinggi, cenderung yakin bahwa dirinya memiliki kemampuan untuk menggunakan teknologi atau komputer. Para peserta juga merasakan bahwa pelatihan ini sangat bermanfaat dan dapat meningkatkan kompetensi penggunaan software ERP mereka. Hal ini dibuktikan juga dengan analisis evaluasi pengetahuan yang menunjukkan penigkatan pengetahuan dari pretes ke postes dibandingkan saat pretes. Hanya saja, untuk evaluasi pembelajaran tidak dilakukan tes tindak lanjut, sehingga peneliti tidak mengetahui efek jangka panjang pengetahuan dari pelatihan yang diberikan.

Berdasarkan observasi, pada awal praktek penggunaan ERP banyak pertanyaan datang dari subjek sehingga pemahaman mereka semakin baik di hari ke dua sehingga para peserta mudah mengikuti panduan dari modul yang diberikan, bahkan lima orang subjek sesekali membantu rekan yang kesulitan. Saat sesi diskusi, para peserta juga sudah mampu memberikan pendapat terkait langkah yang seharusnya diambil oleh rekan-rekan yang masih kesulitan dan bahkan ada peserta yang sudah melakukan perpandingan dengan software ERP dan software Odoo versi lainnya.

\section{DAFTAR PUSTAKA}

Abdallah, M.M.S., \& Mansour, M.M. (2015). Virtual Task-Based Situated LanguageLearning with Second Life: Developing EFL Pragmatic Writing and Technological Self-Efficacy. Arab World English Journal (AWEJ) Special Issue on CALL No.2, 150 - 182. 
Aremu, A., \& Fasan, O. (2011). Teacher training implications of gender and computer self-efficacy for technology integration in Nigerian schools. The African Symposium: An online journal of the African Educational Research Network, 11 (1), $178-185$.

Bantam, D.J. (2016). Odoo human capital configuration. Modul Pembelajaran HRIS. Yogyakarta: Psikologi UII.

Berkant, H.G. (2016). Faculty of education students' computer self-efficacy beliefs and their attitudes towards computers and implementing computer supported education. European Journal of Contemporary Education, 15 (1), 123 - 135. doi: 10.13187/ejced.2016.15.123

Chou, C. M., Hsiao, H. C., Shen, C. H., \& Chen, S. C. (2010). Analysis of factors in technological and vocational school teachers' perceived organizational innovative climate and continuous use of e-teaching: using computer self-efficacy as an intervening variable. The Turkish Online Journal of Educational Technology, 9 (4), $35-48$.

Compeau, D. R., \& Higgins, C. A. (1995). Computer self-efficacy: Development of a measure and initial test. MIS Quartely, 19 (12), $189-211$.

Cummings, T.G. \& Worley, C.G. (2009).Organization development and change. 6th $E d$. South-Western: College Publishing

Cozby, P.C. 2009. Methods in behavioral research. New York: McGrew Hill.

Elmeziane, K., \& Elmeziane, M. (2012). Enterprise resource planning system success in China. Business and Management Review, 1 (12), 1 - 9.

Farah, A. C. (2011). Factors influencing teachers' technology self-efficacy: Case study. Disertasi. Lynchburg: Liberty University.

Hommes \& Molen (2012). Effects of a self-instruction communication skills training on skills, self-efficacy, motivation, and transfer. European Journal of Open, Distance and E-Learning, $1-11$.

Ikonomopoulos, J., Vela, J.C., Smith, W.D., \& Dell'Aquila, J. (2016). Examining the practicum experience to increase counseling students' self-efficacy. The Professional Counselor, 6 (2), 161-173. doi:10.15241/ji.6.2.161

Irfani, M.H. (2015). ERP (enterprise resource planning) dan aspek-aspek penting dalam penerapannya. Eksplora Informatika, 4 (2), 105 - 114.

Leech, N.L., Barret, K.C., \& Morgan, G.A. (2005). SPSS for intermediate statistics: Use and interpretation $2^{\text {nd }}$ Edition. Marwah: Lawrence Erlbaum Associates, Publishers 
Lunenburg, F. C. (2011). Self-efficacy in the workplace: Implications for motivation and performance. International Journal of Management, Business, and Admistration, 14 (1), 1 - 6 .

Monk, E., \& Wagner, B. (2013). Concepts in enterprise resource planning. USA: Course Technology.

Muliawan, J.U. (2010). Penilitian tindakan kelas (classroom action research). Yogyakarta: Gava Media

Raza, S.A., Zia, S., Naqvi, S.A.H., \& Shaikh, F.M. (2011). Human and Social Capital Development for Self Efficacy of University Graduates: Bases for Development of Society. Asian Social Science, 7 (9), 244 - 254.

Sabzian, F., \& Gilakjani, A.P. (2013). Teachers' attitudes about computer technology training, professional development, integration, experience, anxiety, and literacy in English language teaching and learning. International Journal of Applied Science and Technology, 3 (1), $67-75$.

Sam, H. K., Othman, A. E. A., \& Nordin, Z. S. (2005). Computer self-efficacy, computer anxiety, \& attitudes toward the internet: A study among undergraduates in Unimas. Educational Technology \& Society, 8 (4), 205-219.

Shaughnessy, J. J., Zechmeister, E. B. \& Zechmeister, J. S. (2012). Research Methods in Psychology. New York: McGraw Hill.

Singh, T. (2015). Efficacy of training and development programs on employee productivity at Bharat Heavy Electricals Limited. IJAPRR International Peer Reviewed Refereed Journal, 2 (2), 16-24.

Supratiknya, A. (2008). Psikoedukasi: Merancang Program dan Modul. Yogyakarta: Universitas Sanata Darma.

Wang, L., \& Ertmer, P. A. (2015). Vicarious learning experiences and goal setting: Impact on preservice teachers' self-efficacy for technology integration. Report. Purdue University.

Widhiarso, W. (2011). Aplikasi anava campuran untuk untuk desain eksperimen prepost test design. Naskah Publikasi. Yogyakarta: Fakultas Psikologi UGM.

Wiyati, R., Widayanti, E.D. \& Wahyuningsih, D. (2010). Pengaruh Psikoedukasi Keluarga Terhadap Kemampuan Keluarga Dalam Merawat Klien Isolasi Sosial. The Soedirman Journal of Nursing, 5 (2): 85-94 